\title{
Academic inbreeding: local challenge, global problem
}

\author{
Philip G. Altbach ${ }^{1} \cdot$ Maria Yudkevich $^{2}$ Laura E. Rumbley ${ }^{1}$
}

Received: 22 June 2015/Revised: 10 August 2015/Accepted: 12 August 2015/Published online: 23 August 2015

(c) Education Research Institute, Seoul National University, Seoul, Korea 2015

\begin{abstract}
Academic inbreeding"-involving the appointment of faculty members who graduated from the institution employing them-is considered a small and peripheral aspect of the academic profession but is quite widespread globally. This paper analyzes the nature of inbreeding and its impact on universities. Data from eight countries where inbreeding is widespread are analyzed in order to examine the perceived impact of the phenomenon on academics and universities. Our analysis reveals that while inbreeding has deleterious effects on universities, it is widely perceived as a "normal" part of academic lifeand some positive aspects are evident.
\end{abstract}

Keywords Academic inbreeding · Faculty inbreeding · Academic profession

This research project had its origins in a concern at the National Research University-Higher School of Economics in Moscow that the common practice in Russia of hiring one's own graduates for faculty jobs has profound implications for academic culture, productivity, and the essential nature of the university. This interest led to a research project collaboratively organized by the Higher School of Economics and the Boston College Center for International Higher Education, and centered on an examination of academic inbreeding in eight different countries: Argentina, China, Japan, Russia, Slovenia, Spain, South Africa, and Ukraine. This study was funded mainly by the Higher School of Economics. The full results of the research are reported in Yudkevich et al. (2015).

Laura E. Rumbley

rumbley@bc.edu

1 Center for International Higher Education, Boston College, Chestnut Hill, MA 02467, USA

2 National Research University-Higher School of Economics, Moscow, Russian Federation
"Academic inbreeding," involving the appointment of faculty members who graduated from the institution employing them, is often considered a small and peripheral aspect of the academic profession and does not attract much attention from academics or policy-makers. Although seldom discussed, inbreeding is quite common worldwide-and standard practice in dozens of countries. Hiring one's own graduates is considered neither unusual nor problematic in many academic systems. This pattern has been in place for many years-often for centuries-and is quite often considered a point of pride for higher education institutions, in the sense that universities can claim that inbreeding is evidence that they can retain their best intellectual talent.

Our perspective is that faculty inbreeding is problematic and, where it exists, is often associated with a whole range of worrisome issues in relation to the academic and administrative functions of higher education institutions and systems. It limits the scope of hiring the best possible candidates for academic appointments-from both within the country and internationally. Inbreeding tends to entrench the academic culture already existing in the institutions where inbreeding occurs (Padilla 2008), and makes change and reform even more difficult than would normally be the case. It solidifies hierarchical relationships within departments and faculties and enhances the power of senior professors (e.g., Rocca 2007; Godechot and Louvet 2008). It may also create particularism-for example, in the form of applying preferential hiring or promotions standards for some (internal) colleagues or candidates-as opposed to universalism, which implies the same treatment for all (Blau 1973; Bridgeland 1982). Inbreeding may perpetuate unfair power dynamics reflected in society more broadly - and may be particularly detrimental to women and others traditionally excluded from academe (Wyer 1980; Pan 1993). New ideas, 
concerning the academic discipline as well as the organization of studies and the curriculum, may be more difficult to implement. This occurs because both faculty and administrators consider the status quo to be "natural" and beneficial, and their interests are squarely invested in established academic and administrative arrangements. In short, new perspectives and new relationships do not take hold as easily where inbreeding is prevalent, and departments, schools, and the entire university are less innovative and open (for various examples and discussion, see Smythe and Smythe 1944; Pelz and Andrews 1966; Velho and Krige 1984; Horta et al. 2007). In the twenty-first century, where knowledge is rapidly changing and increasingly globalized, inbreeding engenders traditionalism, which limits excellence and innovation.

Inbred faculty tend to be more "local" in their orientation. They exhibit more loyalty and commitment to their university rather than reflecting a "cosmopolitan" orientation, which is typified by a greater focus on their discipline and a broader identification with the academic profession at large (Gouldner 1957). In general, faculty with a local orientation are less focused on research and less involved with the wider academic community (see, e.g., Hollingshead 1938). They invest more in the types of activities that are visible and rewarded within the individual university-i.e., teaching and administrative duties - which are less appreciated by the academic market. Indeed, while publications in peer-reviewed journals or a record of obtaining grants can easily be recognized on a curriculum vitae and increase a professor's "market value," teaching efforts and administrative duties are quite often less visible and difficult to measure for those seeking to move from one institution to another.

While in broad terms academic inbreeding is defined as the practice of universities hiring their own graduates, different authors suggest various ways to consider the operationalization of this term (for a detailed discussion of alternative definitions, see Gorelova and Yudkevich 2015). Some researchers consider as inbred those faculty "who had received all or any part of their training in the institution in which they are teaching" (this approach is used, e.g., in McNeely 1932; Eells and Cleveland 1935; McGee 1960; Hargens and Farr 1973; Dutton 1980; Smyth and Mishra 2013). In many recent studies, authors define academics as inbred if they have obtained their $\mathrm{PhD}$ from the university at which they are now employed, while the source of all other degrees held by the academic is not taken into account (Berelson 1960; Wells et al. 1979; Wyer and Conrad 1984; Eisenberg and Wells 2000; Horta et al. 2007; Cruz-Castro and Sanz-Menéndez 2010).

Other authors introduce more specific definitions of inbreeding. Thus, Navarro and Rivero (2001) consider faculty as inbred if they work at the university where they produced their first publication. Hollingshead (1938) defines inbreeding as "having membership in one of the ingroups: alumni, friendship or family" (Pan 1993, 14).

Many researchers highlight the importance of drawing a distinction between the concepts of "pure inbred" academics and those who are either "silver-corded"-i.e., those academics, whose first employment was not at the university from which they graduated, but later they returned to their alma mater (Caplow and McGee 1958; Berelson 1960; Hargens and Farr 1973; Dutton 1980; Horta 2013; Smyth and Mishra 2013)—or "mobile inbreds," those "who have either spent a research or teaching spell at another university during the doctoral degree or did a postdoc at another university (or did both) before taking the first academic appointment in their Alma Mater" (Horta 2013, 492). Indeed, such distinctions may be critically important because the broader experience (not necessarily having to do with the academic training) of these two latter groups of inbred faculty may have a substantial impact on their productivity and values.

Inbreeding can also be interpreted as the extreme form of academic immobility (Dutton 1980; Horta 2013) and may be compared to other academic career paths-e.g., working in a university other than that from which the individual graduated (adherents), or working in several universities (mobile academics) (Dutton 1980; Cruz-Castro and Sanz-Menéndez 2010; Horta 2013).

Finally, while in most of the literature the definition of inbreeding is based on the fact of graduation from, and employment at, the same university, some researchers define inbreeding in a way that highlights the importance of social ties in the selection process. Thus, Godechot and Louvet (2008) define inbreeding as "a selection process based on personal relationships rather than the standardized evaluation of applications or the thorough analysis of individual skills." Similarly, Rocca (2007) notices that inbreeding emerges in situations where there is a shift in the hiring process from the importance of academic merits toward the importance of social connections.

"Inbreeding" is the most popular term denoting the practice of universities hiring their own graduates, but some authors use other terms that reflect some equally important features of this approach to hiring. Thus, some researchers talk about "endogamy" (highlighting the inevitability of local reproduction) (e.g., Rocca 2007; Godechot and Louvet 2008) or "academic nepotism," where the term itself describes one of the consequences of this practice (Godechot and Louvet 2008). Finally, in some analyses, inbreeding is associated with "localism" (Sivak and Yudkevich 2012).

For the purpose of our discussion, we use (following Berelson 1960 and others) the definition of inbreeding that reflects the situation where a person has worked since graduation at the university from which he or she 
graduated. This definition highlights an important consequence of inbreeding - the absence of external experience.

Initial interest in inbreeding emerged about a century ago, and even at that time, inbreeding was considered to be an unhealthy, problematic practice (see Fitzpatrick 1917; Reeves et al. 1933; Eells and Cleveland 1935; Wilson 1942). Yet, our research revealed not only that a surprising number of institutions and countries have a long tradition of academic inbreeding, but that there are understandable-and in some cases quite pragmatic-reasons for adherence to such practices and policies (Yudkevich et al. 2015). Many countries lack a national labor market for academic jobs or have little or no tradition of mobility. In extreme cases, those academics that seek jobs at other universities may even be considered "outliers," potentially problematic individuals who have been pushed out by their home institutions. With these kinds of prejudices, it becomes difficult for academics to find a good position at another institution, without informal connections. Indeed, in systems with significant levels of inbreeding, informal ties start to play an important role in recruitment and promotion decisions. The interests of senior faculty in hiring their own former students or assistants can be a critical factor influencing recruitment decisions. Ad hoc decision-making and approaches to hiring based on informal ties in many countries coexist with-and overshadow-formal systems of "open" recruitment and meritbased promotion. While procedures (such as open calls for hiring and public competitions for promotion, etc.) are formally in place, nobody believes they really work; such procedures are considered an artificial façade masking the real processes, which are based on personal relationships and "insider" knowledge.

Thus, in many contexts it is quite difficult, in very practical terms, for a graduate of one university to obtain an academic job at a different institution — and few ways of moving from one institution to another once appointed. In small countries, there can be few universities producing doctoral graduates and these national systems may often be overwhelmingly staffed by graduates of a single research university, perhaps complemented by a small number of graduates of foreign institutions.

Graduate schools, as a central place for the training of future academics, play a critical role in reproducing inbreeding practices. In those systems where $\mathrm{PhD}$ candidates are also employed as teaching assistants in their respective departments, inbreeding is often widespread. Up until the moment of their doctoral defense, these individuals are deeply integrated into the department in terms of sharing values and informal ties with their colleagues. In this way, they naturally gain preference over external candidates seeking employment in the department, and unless there are strong norms against hiring "from the inside" or regulations against this practice, it becomes standard practice.

Historical and cultural tradition is perhaps the greatest reason for academic inbreeding-universities often feel that their own graduates not only are the most qualified but, crucially, understand the culture and traditions of the institution; therefore, they will "fit in" to the existing academic community (Padilla 2008). By taking in their own graduates, universities minimize efforts exerted in search and recruitment processes and also minimize the risks of poor hiring decisions (Miller 1977; Dattilo 1986; Majcher 2004). They are able to select the most loyal candidates who share the basic values of the organization and research community (Lafferty 1964), and will work toward further preservation of these values. Continuity and respect for the institution's "academic heritage" is considered an important virtue in these contexts. In turn, the ability of a department to keep its best faculty for years is considered a sign of academic quality.

In most countries where academic inbreeding exists, it is generally not considered a problem. The practice is so commonplace and longstanding in many systems that it is frequently not "considered" at all! The inbreeding arrangement is widely accepted, and universities are perceived to work well and produce appropriate quality in teaching and research. Indeed, some research in a number of countries shows that inbred faculty are not notably less productive in terms of research output than professors who are not inbred (see Clark and Larson 1972; Smyth and Mishra 2013). However, those are exceptions to the general rule. Even early studies of inbreeding showed that inbred faculty produced many fewer books compared to non-inbred academics. If the total number of all publications was taken into account, the difference was not so impressive, but the early analyses still proved lower productivity levels of inbred faculty members (Eells and Cleveland 1935). In later papers, most researchers (Hargens and Farr 1973; Dutton 1980; Eisenberg and Wells 2000; Horta et al. 2007; Inanc and Tuncer 2011; Horta 2013) came to the same conclusions.

It is important to note, however, that researchers who claim that inbred faculty members are not less productive than their non-inbred colleagues do not take into account the quality or innovativeness of the research that is produced by inbred faculty. Indeed, inbred faculty may be more oriented toward local journals and publications than non-inbred academics, as the latter care about global recognition for what they are doing (see Velho and Krige 1984 for the case of Brazil, and Sivak and Yudkevich 2015 for the Russian case). That is, even if inbreed faculty are sometimes "quantitatively" more productive than their 
non-inbred colleagues, such comparisons should be undertaken with great caution and the results interpreted properly. As existing literature shows, countries with a higher level of inbreeding produce a smaller share of the world's research output (measured by publications in leading peer-reviewed journals-see for example Soler 2001).

Despite established traditions of inbreeding in a number of countries, there is a general perception in the academic community globally, when this topic is considered at all, that inbreeding is a negative characteristic, and that worldclass universities should not rely on inbred faculty. Some leading universities even have put "anti-inbreeding" policies into place. For example, many of the top universities in China, including Peking University, no longer hire their own graduates for academic jobs-indeed, many Chinese universities favor hiring Chinese graduates of the best Western universities. Some institutions are increasingly hiring from an international talent pool, with the goal of bringing the best research productivity and methods from abroad, as well as infusing new ideas about university management. Other countries allow universities to hire their own graduates but only after these individuals gain considerable international academic experience. The government-sponsored China Scholarship Council, for example, provides support for Chinese academics to obtain overseas experience. Policy-makers in these countries are well aware of potential negative consequences of inbreeding and believe that it is often correlated with low mobility and poor standards. By stimulating academic mobility, they try to cope with potential negative impacts of limited outside experience and the absence of external connections.

This article reflects a general overview of results from our comparative study-Academic Inbreeding and Mobility in Higher Education: Global Perspectives (Yudkevich et al. 2015). This research examines the scope and nature of inbreeding in eight countries across four continents. We assumed that academic inbreeding would be on the decline worldwide, and that there would be a consensus that the practice should be promptly ended. Our findings, however, do not support this assumption. In most of the eight countries discussed in our study, inbreeding is not seen as a serious problem, even if there is a general recognition that reforms may be useful. Some data show that academic productivity of inbred faculty is not significantly different than for other faculty. However, we remain convinced that the best universities of the twenty-first century will be outward looking, internationally minded, and open to the best academic minds from their countries and the world. These characteristics do not favor hiring "from within."

\section{Comparative perspectives on inbreeding}

Our analysis draws on a comparative picture of inbreeding practices and policies in Argentina, China, Japan, Russia, Slovenia, Spain, South Africa, and Ukraine. All of the countries included in our study have high levels of inbreeding and present an interesting range of perspectives in terms of size of country and national higher education systems, as well as world regions. Each of the country experts involved in the study was asked to complete a common questionnaire (developed specifically for this study-see "Appendix") and has contributed a chapter to the book that fully reports this research (Yudkevich et al. 2015). Our experts gave their opinions (in most cases based on in-depth interviews with policymakers and university administrators) about the importance and prevalence of various phenomena related to inbreeding. The experts were also asked to consider how inbreeding plays out in different segments of the higher education systems in their country (for example, in elite universities versus "average" universities). The questionnaire provided a small set of quantitative data that allow us, to some extent, to compare countries' experiences with inbreeding and to see some common patterns. As will be discussed further, despite considerable differences among our study countries with regard to size and many other important characteristics, they share some commonalities in relation to the rationale, realities, and consequences of inbreeding.

\section{Inbreeding and immobility}

As has already been mentioned, inbreeding and academic immobility (a single-university career) are often associated (see Fig. 1). Indeed, inbreeding is commonly caused by the absence of a domestic academic labor market (especially for senior positions), housing anomalies that affect the possibilities for mobility (such as limited options for apartment rental), as well as cultural values that consider organizations akin to families and reward loyalty and longevity. All these factors contribute in different ways to limited employment mobility and single-university careers.

In terms of consequences, inbreeding and single-university careers are also quite alike since both severely limit outside experience of faculty. They both force faculty to invest in competences, activities, and outputs that are more visible and rewarded within the employing university than outside it. This explains, for example, why inbred and nonmobile faculty usually teach more and spend more time on administrative and service duties than their non-inbred and mobile counterparts (see Dutton 1980; Wyer and 
Fig. 1 National higher education experts' opinions on the degree of academic immobility in their respective country. Source The survey of national higher education experts conducted specifically for this project. Data reflect responses to the project survey with Likert Scale responses ranging from " 1 -phenomenon doesn't exist in the system" to "5-phenomenon is very widespread within the system"

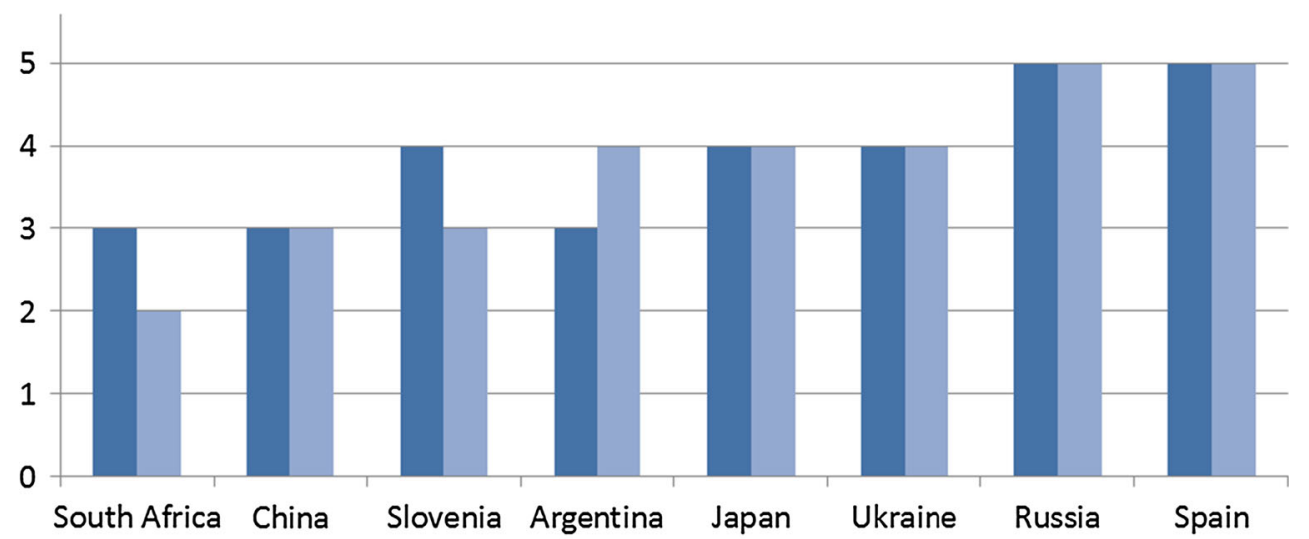

A single-university career (not necessarily at an institution where a person got the highest degree)

Getting the first academic position at the university where the person received their highest degree
Conrad 1984). Limited external experience also induces faculty to accept existing academic routines and practices non-critically, and often be neither interested in, nor able to contribute toward, changing existing standards or models of academic governance.

\section{Inbreeding and prestige}

In our comparative study, we included only countries with high levels of inbreeding, in general terms (Fig. 2). However, inbreeding levels can be different for different segments within a given national higher education system. Indeed, for the countries included in this study (and this is consistent with previous literature on inbreeding - see Berelson 1960; Wells et al. 1979; Im 1990; Pan 1993; Eisenberg and Wells 2000; and Horta et al. 2011) inbreeding is more common among high-quality, elite institutions than in the system on average. There are several reasons for this. First, the best universities believe-in most cases, quite reasonably - that their graduates are the most well-prepared, and find it difficult to recruit outsiders with comparable skills and potential. Second, faculty in top universities actively cooperate with international colleagues and are well integrated into the international academic community. This makes the consequences of inbreeding less harmful in elite university environments.

In contrast, low-quality institutions in many countries demonstrate lower levels of inbreeding than may be seen on average (Fig. 3). However, this is not due to their understanding of the harmful nature of this phenomenon, but is rather explained by the fact that low-quality institutions often do not have their own core faculty, do not produce many doctorates or other advanced degree holders, and must attract faculty from other institutions in order to effectively meet their needs for faculty. In some cases,

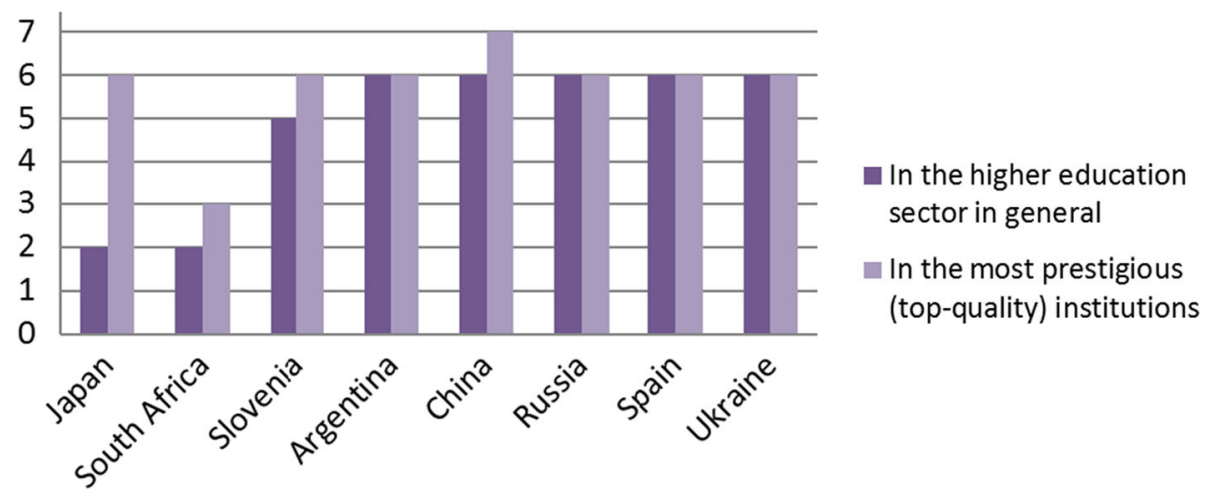

Fig. 2 National higher education experts' opinions on the level of inbreeding in the higher education system in their respective country, on average versus within the most prestigious (top-quality) universities. Source The survey of national higher education experts conducted specifically for this project. Data reflect responses to the project survey with Likert Scale responses ranging from "1phenomenon doesn't exist in the system" to "7-phenomenon is very widespread within the system" 


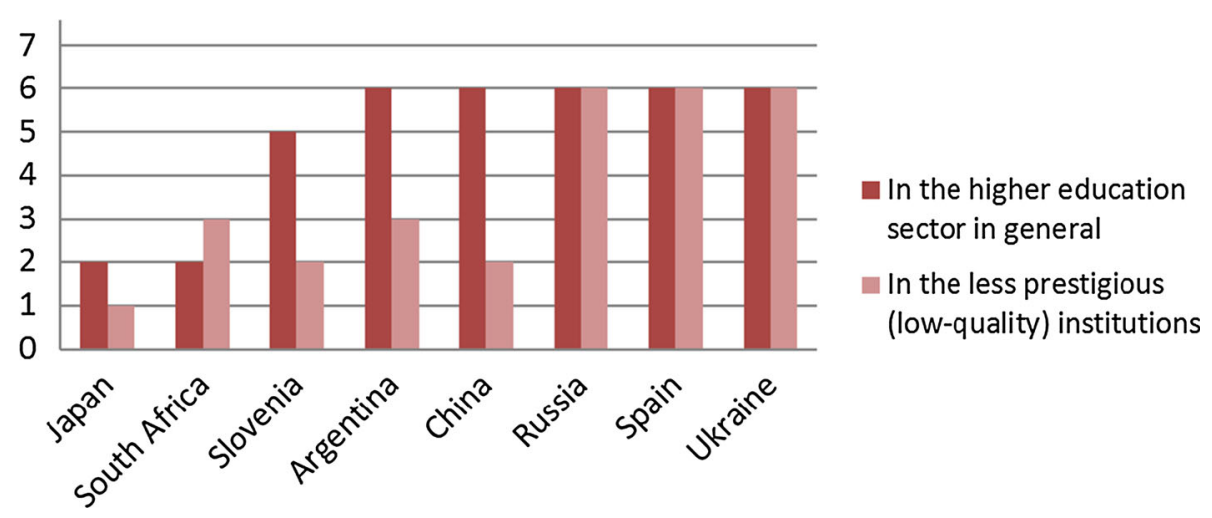

Fig. 3 National higher education experts' opinions on the level of inbreeding in the higher education system in their respective country, on average versus within low-quality universities. Source The survey of national higher education experts conducted specifically for this

faculty in these lower-tier institutions enjoy full-time appointments, while others are engaged on a part-time basis. Such institutions also do not often have their own $\mathrm{PhD}$ programs, which are usually the main source of young faculty when hired from within.

\section{The causes of inbreeding}

As for the reasons why academic inbreeding occurs, there is no general consensus on the most important factors across the study countries. Thus, uncompetitive earnings for academics are mentioned as an important factor for Russia, Argentina, and Spain (see Fig. 4), while in other countries, faculty income seems less important. project. Data reflect responses to the project survey with Likert Scale responses ranging from " $1-$ phenomenon doesn't exist in the system" to "7-phenomenon is very widespread within the system"

Experts from most of the study countries, however, stress the general importance of social ties in this discussion (see Fig. 5). China and South Africa are the only countries where social ties do not represent an important factor supporting inbreeding.

Experts in these countries, as well as in Japan and Slovenia, believe that the preference for internal candidates is shown only when the internal candidate is genuinely perceived to be stronger than the external applicants (see Fig. 6). In other words, in many countries experts believe that there is no prejudice toward external candidates and that inbreeding is in some sense the consequence of deep university beliefs that their own graduates are the most attractive for hiring purposes. We think that these beliefs

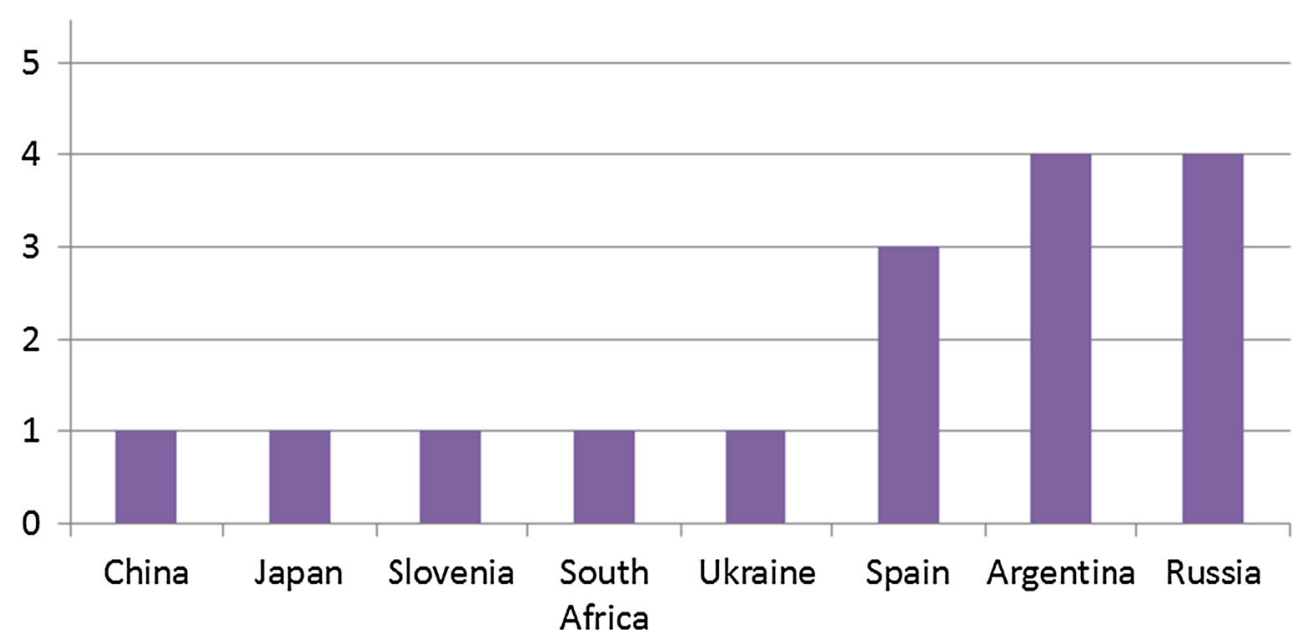

Fig. 4 National higher education experts' opinions on the reasons for academic inbreeding: uncompetitive earnings in academia. Source The survey of national higher education experts conducted specifically for this project. Data reflect responses to the project survey with Likert Scale responses ranging from " 1 - strongly disagree with the statement 'On average, the main reason for academic inbreeding is that earnings in academia are uncompetitive compared to the nonacademic labor market (therefore, it is difficult to attract outside candidates and only those with a prior attachment to a specific university can be effectively recruited)" " to "5-strongly agree with this statement" 


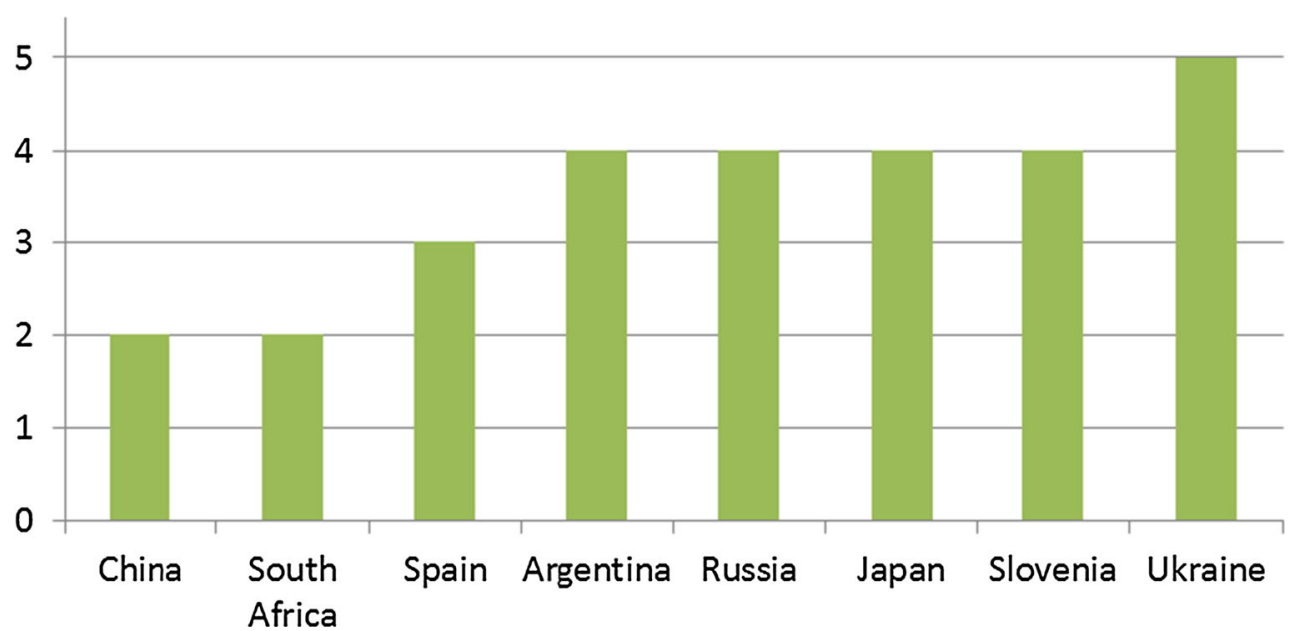

Fig. 5 National higher education experts' opinions on the reasons for academic inbreeding: importance of social ties. Source The survey of national higher education experts conducted specifically for this project. Data reflect responses to the project survey with Likert Scale

responses ranging from " 1 - strongly disagree with the statement 'On average, the main reason for academic inbreeding is that social ties in general have traditionally exerted a strong influence within the academic system", to "5-strongly agree with this statement"

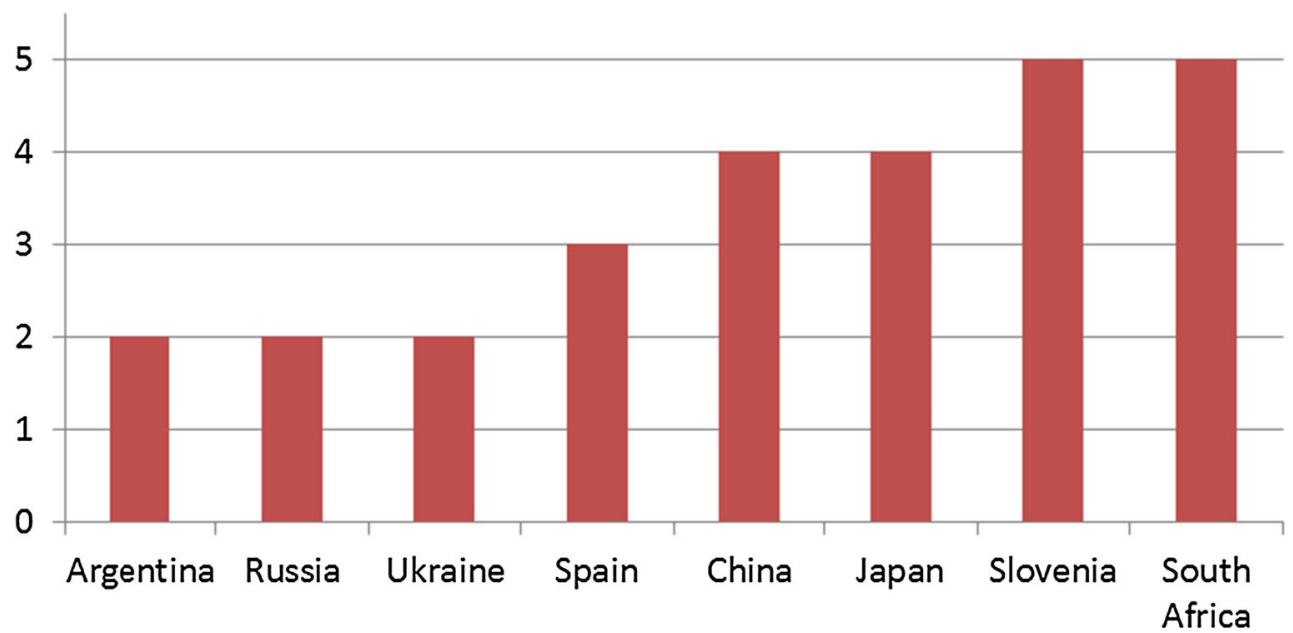

Fig. 6 National higher education experts' opinions on the reasons for academic inbreeding: preference is shown to inbred candidates only when they are more competent than other candidates. Source The survey of national higher education experts conducted specifically for this project. Note Data reflect responses to the project survey with

are critically important for reproducing and sustaining inbreeding over time.

\section{Hiring practices and candidates' prospects}

Hiring procedures in many institutions and systems around the world are organized around "open calls" for positions, with clearly defined job descriptions and candidate prerequisites. Positions also specify the obligations candidates should meet once hired. However, in many countries with
Likert Scale responses ranging from " 1 - strongly disagree with the statement 'Preference is shown to inbred candidates only when they are more competent than other candidates" to "5-strongly agree with this statement"

high levels of inbreeding, these "open and competitive" procedures are essentially pretense, as no one believes in the possibility of genuinely fair chances for outsiders to succeed in these competitions (see Table 1). All parties in the recruitment process understand the "fictitious" nature of such formal procedures. Potential applicants from outside do not feel they have a real chance to be selected and generally do not apply for positions at other universities. University administrators do not really expect to receive external applications during "national" recruitment 
Table 1 National higher education experts' opinions on formal procedures versus real practices [How often an open competition is a "fiction" (1-not at all often, 5-very often)]

Argentina China Japan Russia Slovenia $\begin{aligned} & \text { South } \\ & \text { Africa }\end{aligned}$

Spain Ukraine Africa

Please indicate how often an open competition is a "fiction" 4

1

$\begin{array}{llll}3 & 5 & 5 & 1\end{array}$

$1+4 \quad 4$

processes, and may not even have any procedures to deal with external applications, in the event any were received. Finally, incumbent faculty facing contract renewal, which is often done through an open call for the position up for renewal, may not feel any competitive pressure, knowing that the "competition" is, in reality, quite limited. In Argentina, an extreme case, universities must legally open up every contract renewal nationally, although no one but the incumbent ever actually applies for these "open" jobs.

The existence of a huge gap between formal procedures for hiring and actual practices suggests that inbreeding could not be eliminated by the simple introduction of formal requirements to have open, nondiscriminatory policies toward outside candidates. While formal procedures may exist, and even be supported by such mechanisms as the publication of open calls in national newspapers, real practices are guided by entrenched informal conventions and routines that limit the hiring of outsiders. So, when asked why inbreeding is a prevailing reality in their institutions, university administrators often refer to the fact that no outside applications are received, which explains the pervasiveness of internal hiring.

Overall, our study experts agree that it is relatively difficult to obtain a university position, especially one that offers long-term guarantees and job security
(Fig. 7). The only exception to this trend across the case study countries is Russia, but even here the field is becoming more competitive, as the Russian government launched in 2013 many important initiatives aimed at restructuring some Russian higher education institutions. More competition for academic positions in Russia is also due to the current demographic "dip": The cohort of young people is shrinking, meaning fewer students are entering universities, so fewer teachers are needed to teach them.

Almost all of our study experts claim that in their national systems (even where there is considerable inbreeding) candidates' professional qualifications (measured, for example, by publications records) play an important role in decision-making around faculty recruitment and hiring (Fig. 8).

In this regard, our study experts do not see much difference between the elite sector and all other higher education institutions in their respective countries. Work experience in academic institutions is somewhat less important (Fig. 9), especially in Japan and Russia. Finally, in more than half of the countries that were the focus of our study, experts report that being a graduate from the hiring institution is not an important factor per se for recruitment decisions (Fig. 10).
Fig. 7 National higher education experts' opinions on the ease of finding academic employment. Source The survey of national higher education experts conducted specifically for this project. Note Data reflect responses to the project survey with Likert Scale responses ranging from " 1 very difficult to get an academic position" to "5-very easy to get an academic position"

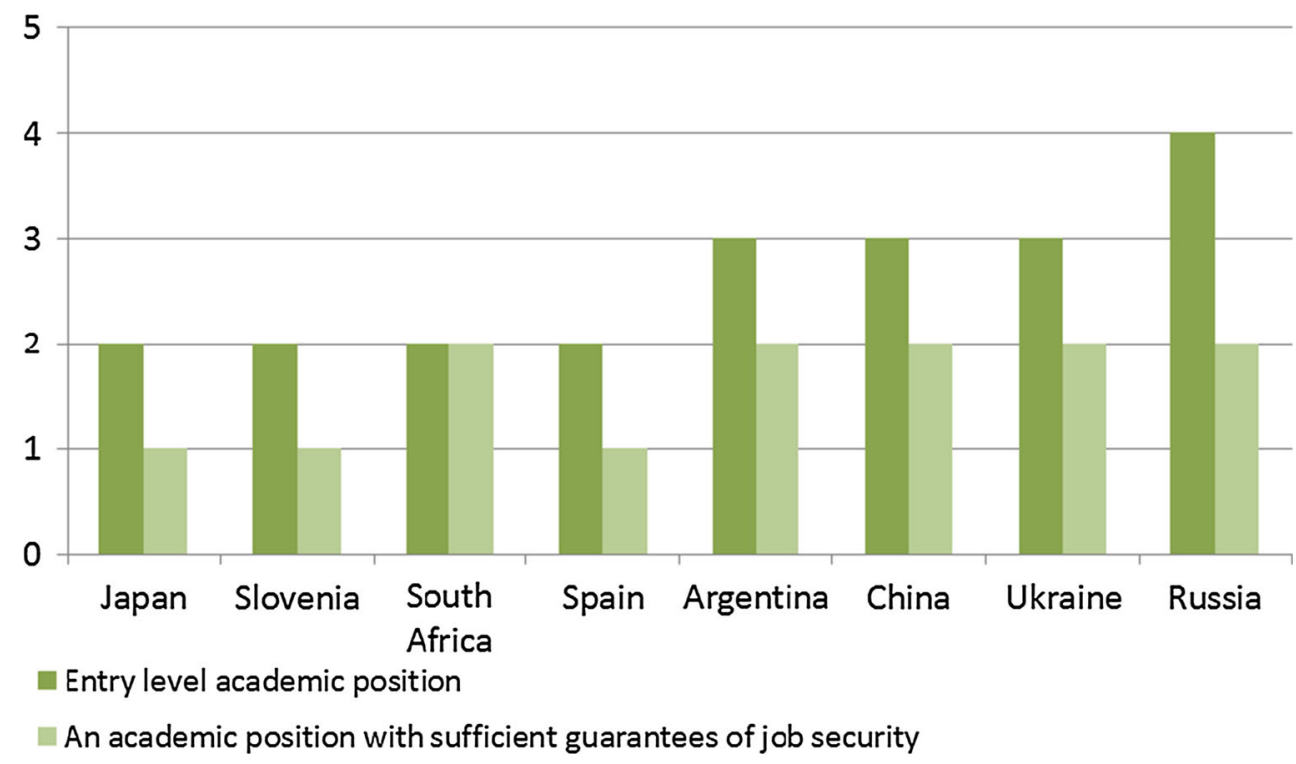


Fig. 8 National higher education experts' opinions on the importance of various factors in faculty hiring decisions: professional output (such as published papers, etc.). Source The survey of national higher education experts conducted specifically for this project

Fig. 9 National higher education experts' opinions on the importance of various factors in faculty hiring decisions: previous work experience in academic institutions. Source The survey of national higher education experts conducted specifically for this project. Data reflect responses to the project survey with Likert Scale responses ranging from " 1 -not at all important" to "5-very important"

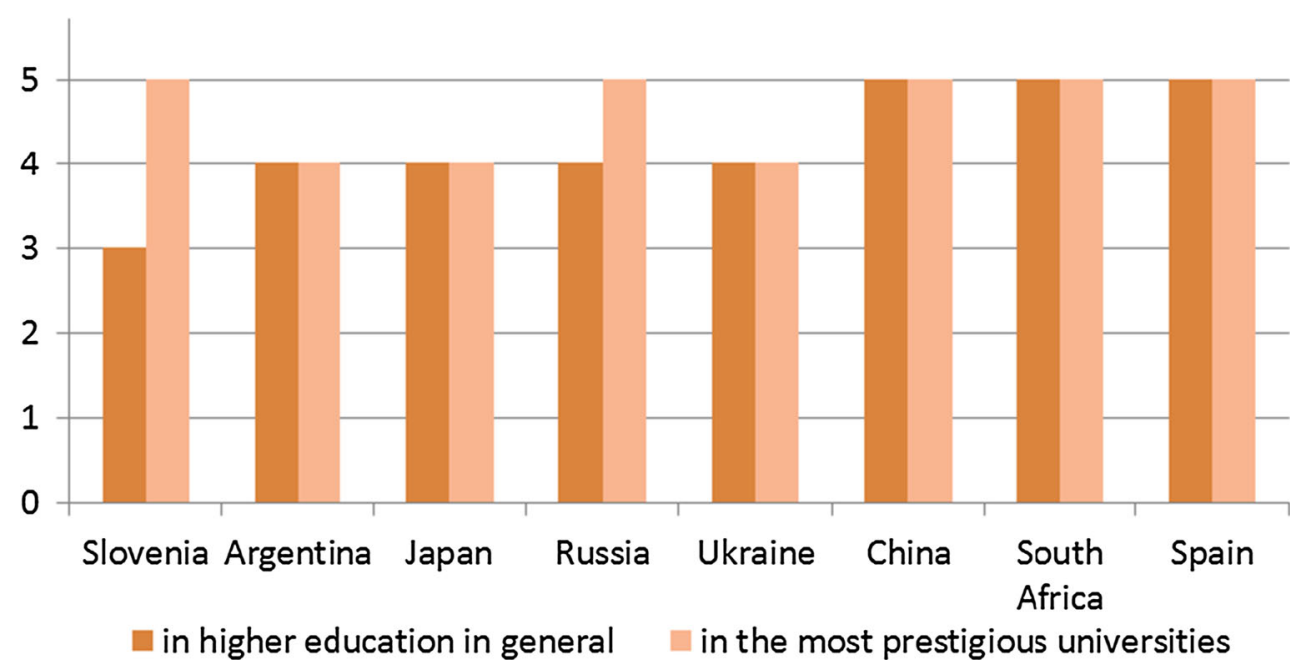

in higher education in general $\square$ in the most prestigious universities

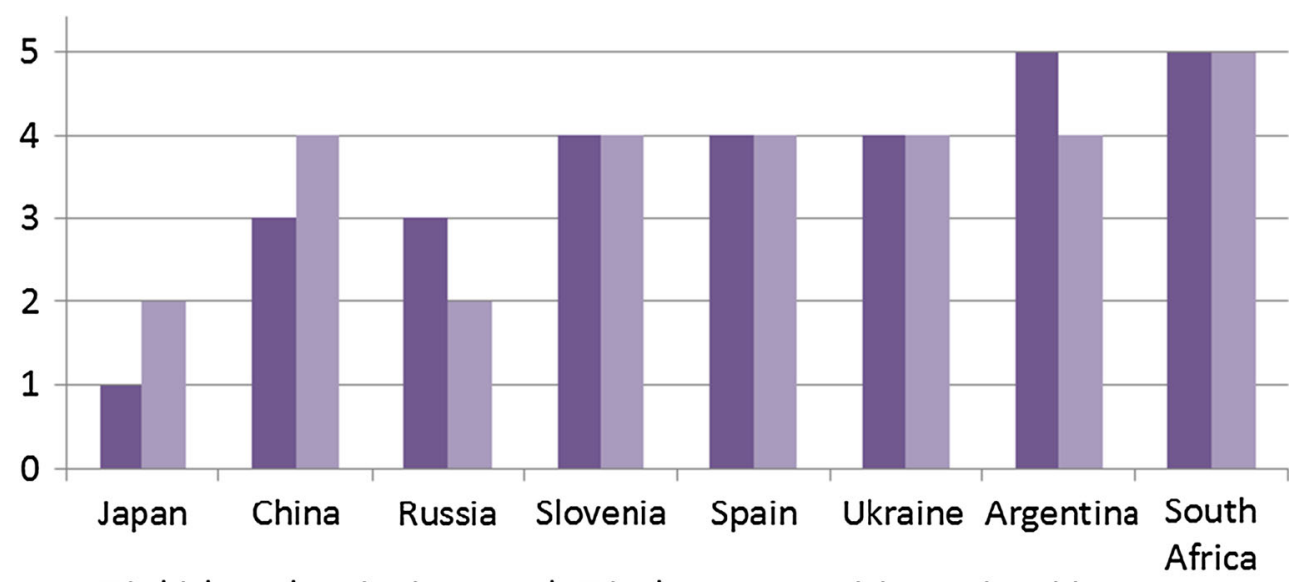

a in higher education in general $\square$ in the most prestigious universities

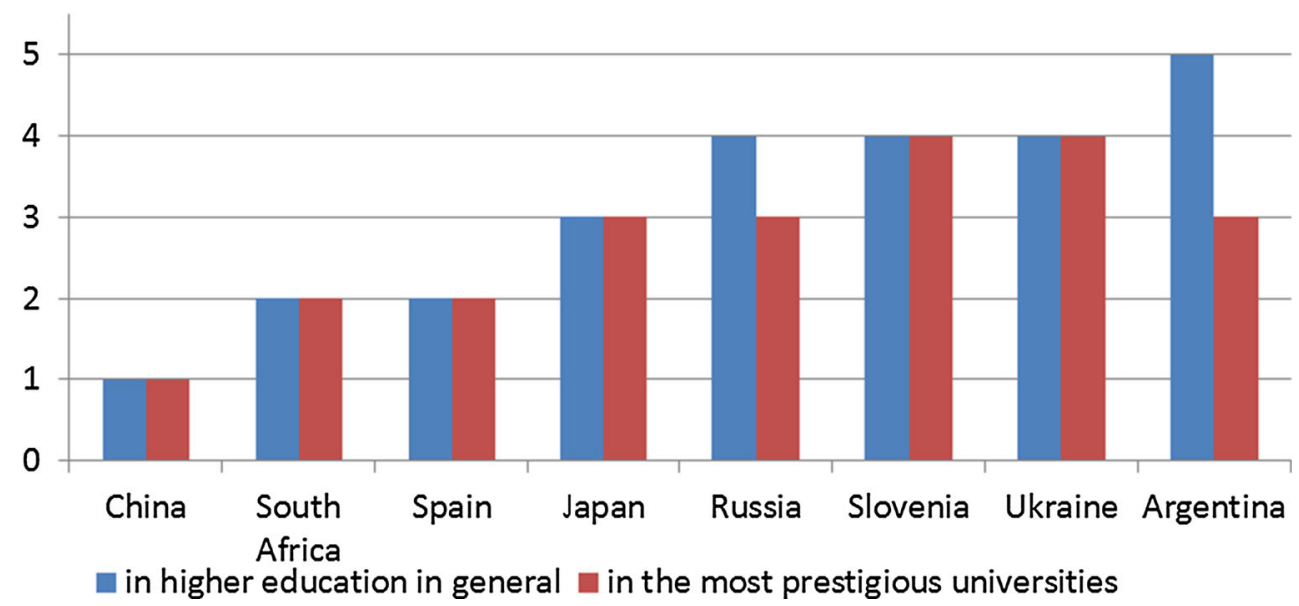

m in higher education in general $\square$ in the most prestigious universities
Fig. 10 National higher education experts' opinions on the importance of various factors in faculty hiring decisions: The job applicant is a graduate of the hiring university. Source The survey of national higher education experts conducted specifically for this project. Data reflect responses to the project survey with Likert Scale responses ranging from " 1 -not at all important" to " 5 -very important" 


\section{The Good, the bad...the inevitable?}

Our brief comparative analysis demonstrates that there are similarities as well as differences in the ways that inbreeding plays out in our study countries-and, we suspect, elsewhere around the world. Importantly, there is no general consensus about what causes inbreeding. Through our project survey work, but also in light of the extensive country case studies included with our full study (Yudkevich et al. 2015), we see that inbreeding is a complex phenomenon with many interrelated aspects. Inbreeding occurs in both big and small systems. It seems to take hold and be perpetuated for a broad range of reasons, including, but not limited to, nonexistent or weak national academic labor markets; limited sources of employable PhD holders; traditions of immobility in both employment and society; lack of faith in candidate screening and hiring mechanisms that do not involve personal ties; and national language policies limiting possibilities to hire nonlocal academics.

Low academic salaries, especially in countries that have consistent salaries across institutions, may also limit mobility by removing any economic incentives for moving and making it difficult to move from one place to another and locate affordable housing.

Our research also shows that inbreeding can occur even if universities believe they are hiring fairly and competitively. In these inbred contexts, we note a kind of vicious circle: Inbreeding results in low outside experience of faculty members which, in turn, limits their understanding of inefficiencies within the system in which they work, and minimizes their awareness of possible alternatives for their institution's organization and performance. In other words, while inbred faculty members may, in some cases, be similarly productive in terms of research as their externally recruited peers, they are likely to be more locally oriented and tied to local norms and values and probably less interested in innovating within the university.

Inbreeding frames the lifetime professional experience of a huge number of academics around the world. The fact that this practice is sustained in so many different contexts, in an era of enormous growth and new relevance of higher education to economic and social development, makes it exceedingly important to understand why inbreeding occurs and the consequences it yields. Our starting point for this exercise was that inbreeding is fundamentally problematic. We still feel this is the case, yet the deeper analysis afforded to us through this study has given us new perspectives on the very pragmatic reasons why inbreeding may occur, and the practical difficulties associated with "undoing" this approach to hiring new faculty. In this sense, inbreeding is often a "symptom" of broader systemic issues and can be understood as a "lesser evil" approach in less-than-ideal environments for academic employment. This highlights a daunting reality: "Fixing" inbreeding would not necessarily solve the much more deeply entrenched difficulties inherent in national higher education systems that are structurally misaligned with the notions of "academic labor markets" (regionally or nationally), or social/professional mobility, or in small country contexts where language barriers make it hard to hire anyone but a local graduate. Moreover, abandoning inbreeding without rethinking the broader system of contract relationships may decrease the incentives for new generations of prospective faculty, making them reluctant to choose an academic career under conditions of problematic and uncertain employment and promotion procedures.

Universities worldwide are under unprecedented pressures. The research universities at the top of academic systems face challenges to improve their research profiles, boost their standings in the rankings, and internationalize their faculty and students. Other academic institutions face the challenges of massification, increasing privatization, MOOCs and distance education, and increased diversification of student populations. These enormous challenges require openness to new ideas and a broad perspective that an inbred faculty is unlikely to have.

Although addressing these higher-order challenges is beyond the scope of our study, what this analysis does contribute to the discussion is a clear call to higher education stakeholders around the world that inbreedingoften passively accepted as part of the inevitable status quo-must be pulled out of the shadows and critically examined. Where detrimental effects are identified, these must be constructively addressed. In an era of heightened competition for resources and greatly expanded expectations from society, universities the world over face new challenges and opportunities. These new realities require institutions to undertake careful analyses of all manner of practices that affect their performance, not the least of which are attraction and retention of academic staff. Following established patterns without questioning their contemporary relevance and value is an unwise course of action for any university today. Making sense of academic inbreeding is a higher education agenda item whose time has come.

\section{Appendix: Academic inbreeding—questionnaire}

Dear colleagues, Please note that by "academic inbreeding" we mean here a policy of employment favoring a university's own graduates who have little to no significant working experience at another academic institution. Similarly "inbred candidates" are those individuals who have been hired immediately (or nearly immediately) following 
graduation at the same institution from which they have just graduated.

1. In your country, on average, how difficult is it to get...

\begin{tabular}{|c|c|c|c|c|c|}
\hline & $\begin{array}{l}\text { Very easy } \\
1\end{array}$ & 2 & 3 & 4 & $\begin{array}{l}\text { Very difficult } \\
5\end{array}$ \\
\hline 1. An entry-level academic position in a higher education institution & 1 & 2 & 3 & 4 & 5 \\
\hline \multirow[t]{2}{*}{ 2. An academic position with sufficient guarantees of job security } & 1 & 2 & 3 & 4 & 5 \\
\hline & 1 & 2 & 3 & 4 & 5 \\
\hline
\end{tabular}

2. Please indicate your views on the following statements concerning salary earnings for academics in your country

\begin{tabular}{|c|c|c|c|c|c|}
\hline & $\begin{array}{l}\text { Strongly } \\
\text { agree } \\
1\end{array}$ & 2 & 3 & 4 & $\begin{array}{l}\text { Strongly } \\
\text { disagree } \\
5\end{array}$ \\
\hline $\begin{array}{l}\text { 1. Average academic salary (with all rewards, bonuses and allowances) for full-time faculty is } \\
\text { competitive in relation to salaries in other sectors (for workers with similar qualifications) }\end{array}$ & 1 & 2 & 3 & 4 & 5 \\
\hline 2. Only average top-level salaries are competitive in relation to salaries in other sectors & 1 & 2 & 3 & 4 & 5 \\
\hline $\begin{array}{l}\text { 3. Only average salaries of full-time senior scholars are competitive with average salaries of other } \\
\text { professionals with comparative education }\end{array}$ & 1 & 2 & 3 & 4 & 5 \\
\hline \multirow{2}{*}{$\begin{array}{l}\text { 4. Average academic earnings are competitive to other sectors only if a person has supplementary } \\
\text { employment within the same university (teaching overload, research, administrative duties, etc.) or at } \\
\text { other universities }\end{array}$} & 1 & 2 & 3 & 4 & 5 \\
\hline & 1 & 2 & 3 & 4 & 5 \\
\hline
\end{tabular}

3. Please indicate the degree to which each of the following hiring practices in higher education institutions are widespread

\begin{tabular}{|c|c|c|c|c|c|}
\hline & $\begin{array}{l}\text { Very } \\
\text { widespread } \\
1\end{array}$ & 2 & 3 & 4 & $\begin{array}{l}\text { Not at all } \\
\text { widespread } \\
5\end{array}$ \\
\hline $\begin{array}{l}\text { 1. Open competition (whereby candidates from inside and outside the institution may apply on the } \\
\text { equal basis) }\end{array}$ & 1 & 2 & 3 & 4 & 5 \\
\hline 2. Competition between internal candidates & 1 & 2 & 3 & 4 & 5 \\
\hline $\begin{array}{l}\text { 3. Assignment to a position (whereby appointments are made without use of a formal application or } \\
\text { competitive process among candidates) }\end{array}$ & 1 & 2 & 3 & 4 & 5 \\
\hline 4. Other (please indicate) & 1 & 2 & 3 & 4 & 5 \\
\hline
\end{tabular}

4. Please indicate how often an open competition is a "fiction" (e.g., a person for an advertised position has already been found)

\begin{tabular}{llllc}
\hline $\begin{array}{l}\text { Very } \\
\text { often }\end{array}$ & & & Not at all \\
often \\
1
\end{tabular}


5. Please indicate how important these factors are in faculty hiring decisions
1. Yes

2. No

\begin{tabular}{|c|c|c|c|c|c|}
\hline & $\begin{array}{l}\text { Very } \\
\text { important } \\
1\end{array}$ & 2 & 3 & 4 & $\begin{array}{l}\text { Not at all important } \\
5\end{array}$ \\
\hline 1. Work experience in academic institutions & 1 & 2 & 3 & 4 & 5 \\
\hline 2. Work experience outside academic institutions & 1 & 2 & 3 & 4 & 5 \\
\hline 3. Professional research competences & 1 & 2 & 3 & 4 & 5 \\
\hline 4. Professional teaching competences & 1 & 2 & 3 & 4 & 5 \\
\hline 5. Professional results (such as published papers etc.) & 1 & 2 & 3 & 4 & 5 \\
\hline 6. If a person is a university's own graduate & 1 & 2 & 3 & 4 & 5 \\
\hline 7. Kinship or other social ties & 1 & 2 & 3 & 4 & 5 \\
\hline $\begin{array}{l}\text { 8. Other (please } \\
\text { indicate) }\end{array}$ & 1 & 2 & 3 & 4 & 5 \\
\hline
\end{tabular}

6. Please indicate how important these factors are in faculty hiring decisions in the most prestigious universities 7. On
9. Are there any formal restrictions to hire universities' own graduates right after their graduation (without any

\begin{tabular}{|c|c|c|c|c|c|}
\hline & $\begin{array}{l}\text { Very } \\
\text { important } \\
1\end{array}$ & 2 & 3 & 4 & $\begin{array}{l}\text { Not at all important } \\
5\end{array}$ \\
\hline 1. Work experience in academic institutions & 1 & 2 & 3 & 4 & 5 \\
\hline 2. Work experience outside academic institutions & 1 & 2 & 3 & 4 & 5 \\
\hline 3. Professional research competences & 1 & 2 & 3 & 4 & 5 \\
\hline \multicolumn{6}{|l|}{ 4. Professional teaching competences } \\
\hline \multicolumn{6}{|l|}{ 5. Professional results (such as published papers etc.) } \\
\hline 6. If a person is a university's own graduate & 1 & 2 & 3 & 4 & 5 \\
\hline 7. Kinship or other social ties & 1 & 2 & 3 & 4 & 5 \\
\hline $\begin{array}{l}\text { 8. Other (please } \\
\text { indicate) }\end{array}$ & 1 & 2 & 3 & 4 & 5 \\
\hline
\end{tabular}

average, is it considered desirable among graduates to get an academic position at the same higher education institution from which they have just graduated?

1. Yes

2. No

8. On average, is it considered normal (appropriate?) for a university to hire its own graduates right after their graduation (without any significant work experience at another academic institution)? significant work experience at another academic institution)?

1. Yes, there are legal restrictions on a state/government level

2. Yes, most universities set such restrictions by themselves

3. No, there are no such restrictions

10. On average, how widespread is the following

\begin{tabular}{|c|c|c|c|c|c|}
\hline & $\begin{array}{l}\text { Very } \\
\text { widespread } \\
1\end{array}$ & 2 & 3 & 4 & $\begin{array}{l}\text { Not at all } \\
\text { widespread } \\
5\end{array}$ \\
\hline $\begin{array}{l}\text { 1. A single-university career (not necessarily at an institution where a person got the highest } \\
\text { degree) }\end{array}$ & 1 & 2 & 3 & 4 & 5 \\
\hline $\begin{array}{l}\text { 2. Getting the first academic position at the university where the person received their } \\
\text { highest degree }\end{array}$ & 1 & 2 & 3 & 4 & 5 \\
\hline
\end{tabular}


11. Please indicate your views on the following statements about inbred candidates

\begin{tabular}{|c|c|c|c|c|c|}
\hline & $\begin{array}{l}\text { Strongly } \\
\text { agree } \\
1\end{array}$ & 2 & 3 & 4 & $\begin{array}{l}\text { Strongly } \\
\text { disagree } \\
5\end{array}$ \\
\hline 1. Inbred candidates are hired more often at the most prestigious universities than at other universities & 1 & 2 & 3 & 4 & 5 \\
\hline $\begin{array}{l}\text { 2. Inbred candidates are hired more often to fixed-term positions rather than to permanent positions (i.e. } \\
\text { tenure-track appointments or approximate equivalents) }\end{array}$ & 1 & 2 & 3 & 4 & 5 \\
\hline 3. Inbred candidates are hired more often to teaching positions rather than research positions & 1 & 2 & 3 & 4 & 5 \\
\hline \multirow{2}{*}{$\begin{array}{l}\text { 4. In hard-to-staff areas (like law, medicine, etc., where non academic labor market provides better job } \\
\text { opportunities) inbred candidates are hired more often than in other areas }\end{array}$} & 1 & 2 & 3 & 4 & 5 \\
\hline & 1 & 2 & 3 & 4 & 5 \\
\hline
\end{tabular}

12. Please indicate your views on the following statements

\begin{tabular}{|c|c|c|c|c|c|}
\hline & $\begin{array}{l}\text { Strongly } \\
\text { agree } \\
1\end{array}$ & 2 & 3 & 4 & $\begin{array}{l}\text { Strongly } \\
\text { disagree } \\
5\end{array}$ \\
\hline $\begin{array}{l}\text { 1. On average, the main reason for academic inbreeding is that earnings in academia are uncompetitive } \\
\text { compared to the nonacademic labor market (therefore, it is difficult to attract outside candidates and } \\
\text { only those with a prior attachment to a specific university can be effectively recruited) }\end{array}$ & 1 & 2 & 3 & 4 & 5 \\
\hline $\begin{array}{l}\text { 2. On average, the main reason for academic inbreeding is that social ties in general have traditionally } \\
\text { exerted a strong influence within the academic system }\end{array}$ & 1 & 2 & 3 & 4 & 5 \\
\hline 3. Preference is shown to inbred candidates only when they are more competent than other candidates & 1 & 2 & 3 & 4 & 5 \\
\hline $\begin{array}{l}\text { 4. Inbred candidates are hired only if a university is forced to use this hiring policy (e.g., where there is a } \\
\text { lack of financial resources to compete for external academics; unfavorable geographic location of a } \\
\text { university, etc.) }\end{array}$ & 1 & 2 & 3 & 4 & 5 \\
\hline
\end{tabular}

13. Please estimate the general level of university inbreeding in your country

\begin{tabular}{|c|c|c|c|c|c|c|c|}
\hline & $\begin{array}{l}\text { Very } \\
\text { widespread } \\
1\end{array}$ & 2 & 3 & 4 & 5 & 6 & $\begin{array}{l}\text { Not at all widespread } \\
7\end{array}$ \\
\hline 1. In the higher education sector in general & 1 & 2 & 3 & 4 & 5 & 6 & 7 \\
\hline 2. In the most prestigious (top-quality) institutions & 1 & 2 & 3 & 4 & 5 & 6 & 7 \\
\hline 3. In the less prestigious (low-quality) institutions & 1 & 2 & 3 & 4 & 5 & 6 & 7 \\
\hline
\end{tabular}

\section{References}

Berelson, B. (1960). Graduate education in the United States. New York: McGraw Hill.

Blau, P. M. (1973). The organization of academic work. New York: John Wiley.

Bridgeland, W. M. (1982). Departmental image and the inbreeding taboo within large universities. College Student Journal, 16(3), 287-289.

Caplow, T., \& McGee, R. (1958). The academic marketplace. New York: Basic Books.

Clark, S., \& Larson, R. (1972). Mobility, productivity and inbreeding at small colleges: A comparative study. Sociology of Education, 45(4), 426-434.
Cruz-Castro, L., \& Sanz-Menéndez, L. (2010). Mobility versus job stability: Assessing tenure and productivity outcomes. Research Policy, 39(1), 27-38.

Dattilo, J. E. (1986). The scholarly productivity of inbred and noninbred full-time doctorally-prepared nursing faculty in teaching positions in the South. Doctoral dissertation, Georgia State University.

Dutton, J. E. (1980). The impact of inbreeding and immobility on the professional role and scholarly performance of academic scientists. In Paper presented at the annual meeting of the american educational research association (Boston, MA, April 7-11, 1980). Retrieved from http://eric.ed.gov/?id=ED196714

Eells, W. C., \& Cleveland, A. C. (1935). Faculty inbreeding. Journal of Higher Education, 6(5), 261-269. 
Eisenberg, T., \& Wells, T. T. (2000). Inbreeding in law school hiring: Assessing the performance of faculty hired from within. Journal of Legal Studies, 29(S1), 369-388.

Fitzpatrick, E. A. (1917). Academic inbreeding. School and Society, 6, 679-681.

Godechot, O., \& Louvet, A. (2008). Academic Inbreeding: An Evaluation. Laviedesidees.fr. Retrieved from http://www.book sandideas.net/Academic-Inbreeding-An-Evaluation.html

Gorelova, O., \& Yudkevich, M. (2015). Academic inbreeding: State of the literature. In M. Yudkevich, P. G. Altbach, \& L. E. Rumbley (Eds.), Academic inbreeding and mobility in higher education: Global perspectives (pp. 130-155). New York: Palgrave Macmillan.

Gouldner, A. W. (1957). Cosmopolitans and locals: Toward an analysis of latent social roles-I. Administrative Science Quarterly, 2(3), 281-306.

Hargens, L. L., \& Farr, G. M. (1973). An examination of recent hypotheses about institutional inbreeding. American Journal of Sociology, 78(6), 1381-1402.

Hollingshead, A. B. (1938). Ingroup membership and academic selection. American Sociological Review, 3, 826-833.

Horta, H. (2013). Deepening our understanding of academic inbreeding effects on research information exchange and scientific output: New insights for academic based research. Higher Education, 65(4), 487-510.

Horta, H., Veloso, F., \& Grediaga, R. (2007). Navel gazing: Academic inbreeding and scientific productivity. Management Science, 56(3), 414-429.

Horta, H., Sato, M., \& Yonezawa, A. (2011). Academic inbreeding: Exploring its characteristics and rationale in Japanese universities using a qualitative perspective. Asia Pac Educ Rev, 12(1),35-44.

Im, Y. (1990). The nature and determinants of faculty inbreeding in Korean higher education. Doctoral dissertation, State University of New York at Albany.

Inanc, O., \& Tuncer, O. (2011). The effect of academic inbreeding on scientific effectiveness. Scientometrics, 88(3), 885-898. doi:10. 1007/s11192-011-0415-9.

Lafferty, H. M. (1964). Of time and the teachers colleges in Texas. Peabody Journal of Education, 24(1), 14-22.

Majcher, A. (2004). Mobility and academic career: Reforming the 'inbreeding' system in Central and Eastern Europe. In T. Gabaldón, H. Horta, D. M. Meyer, \& J. B. Pereira-Leal (Eds.), Career paths and mobility of researchers in Europe, (pp. 158-161). Lisbon. http://in3.dem.ist.utl.pt/docs/Career_paths_ and_mobility_of_researchers_in_Europe.pdf

McGee, R. (1960). The function of institutional inbreeding. American Journal of Sociology, 65(5), 483-488.

McNeely, J. H. (1932). Faculty inbreeding in land-grant colleges and universities. Washington: U.S. Government Printing Office.
Miller, M. H. (1977). Academic inbreeding in nursing. Nursing Outlook, 25, 171-177.

Navarro, A., \& Rivero, A. (2001). High rate of inbreeding in Spanish universities. Nature 410, 14.

Padilla, L. E. (2008). How has Mexican faculty been trained? A national perspective and a case study. Higher Education, 56(2), 167-183.

Pan, S. (1993). A study of faculty inbreeding at eleven land-grant universities. Doctoral dissertation, Iowa State University.

Pelz, D. C., \& Andrews, F. M. (1966). Scientists in organizations. New York: Wiley.

Reeves, F. W., et al. (1933). The University Faculty. University of Chicago Survey III.

Rocca, F. X. (2007). In Spain, inbreeding threatens academia. Chronicle of Higher Education. http://chronicle.com/article/InSpain-Inbreeding-Threatens/11068

Sivak, E., \& Yudkevich, M. (2012). University inbreeding: An impact on values, strategies and individual productivity of faculty members. Social Science Research Network,. doi:10.2139/ssrn. 1996417.

Sivak, E., \& Yudkevich, M. (2015). In Yudkevich, M., Altbach, P. G. \& Rumbley, L. E. (Eds.), Academic Inbreeding and Mobility in Higher Education: Global Perspectives (pp. 130-155). New York: Palgrave Macmillan.

Smyth, R., \& Mishra, V. (2013). Academic inbreeding and research productivity and impact in Australian law schools. Scientometrics, 98(1), 583-618.

Smythe, H. H., \& Smythe, M. M. (1944). Inbreeding in Negro college faculties. School and Society, 59, 430-432.

Soler, M. (2001). How inbreeding affects productivity in Europe. Nature, 411, 132.

Velho, L., \& Krige, J. (1984). Publication and citation practices of Brazilian agricultural scientists. Social Studies of Science, 14(1), $45-62$.

Wells, R. A., Hassler, N., \& Sellinger, E. (1979). Inbreeding in social work education: An empirical examination. Journal of Education for Social Work, 15(2), 23-29.

Wilson, Logan. (1942). The academic man: A study in the sociology of a profession. New York: Oxford University Press.

Wyer, J. C. (1980). Institutional origin: Labor market signaling in higher education. Doctoral dissertation, The College of William and Mary.

Wyer, J. C., \& Conrad, C. F. (1984). Institutional inbreeding reexamined. American Educational Research Journal, 21(1), 213-225.

Yudkevich, M., Altbach, P. G., \& Rumbley, L. E. (Eds.). (2015). Academic inbreeding and mobility in higher education: Global perspectives. New York: Palgrave Macmillan. 